\title{
Thymic Tumor Clinical Distant Metastasis TNM Finding v8
}

National Cancer Institute

\section{Source}

National Cancer Institute. Thymic Tumor Clinical Distant Metastasis TNM Finding v8. NCI Thesaurus. Code C136295.

A clinical finding about one or more characteristics of a thymic tumor, following the rules of the TNM AJCC v8 classification system as they pertain to distant metastases. 